forward with the evidence is not so heavy as to nullify the remedy. While it is true that the fallibility of juries and the time lag inherent in any action for damages render the remedy imperfect, ${ }^{\text {sI }}$ the threat of liability would at least be a partial deterrent to the conscious liar..$^{52}$

The cost of imposing procedural and judicial restrictions on congressional investigations, namely the loss of information otherwise available to the public, does not seem prohibitive. The fear is rather that the reforms will not be adequate to protect against unwarranted damage to reputation. Unfairness results not alone from activities within the committee room, but also from a public opinion which is swift to condemn where the charge is one of subversive activity. But since committee actions have a significant share in the molding of public opinion, the suggested reforms may well serve to alter the popular propensity to exaggerate the charges and to pronounce judgment without evidence, and remind us to be patient in judging those who are suspect and whom we do not like.

\title{
THE STATUS OF HOTELS UNDER THE FEDERAL HOUSING AND RENT ACT*
}

The Federal Housing and Rent Act of $1947^{2}$ was enacted by Congress in order

${ }^{5 x}$ It might also be thought that a possibility of injustice is inherent in a plan to abrogate absolute privilege as a result of the power of the legislative committee to compel testimony. It is possible that a witness under subpoena might be forced against his will to make defamatory statements that he believed true, while he would be unable to prove either the truth of the statement or non-abuse of his privilege. Such a remote possibility seems best prevented by a legislative rule granting a witness at a public hearing the privilege of refusing to make possibly defamatory statements. A hearing might result in which the names of persons accused of wrongdoing would be withheld; it would find its prototype in Miss Bentley's testimony before the Ferguson Committee. Hearings before the Investigations Subcommittee of the Senate Committee on Expenditures in the Executive Departments, on Export Policy and Loyalty, 8oth Cong. 2 d Sess. (I948). This privilege from testifying should not extend to secret or executive sessions, though the committee should not be permitted to publish statements made during such proceedings without the permission of the witness. A further advantage in enacting a rule permitting refusal to utter defamatory remarks is to be found in the aid it would give the courts in rejecting a rule of absolute privilege that was prompted in large part by the fact that witnesses in legislative investigations could be compelled to testify. Thus, the rule of Wright $v$. Lathrop, I49 Mass. 385,2 I.E. 963 (I889), allowing only a qualified privilege to the witness who volunteered unsolicited information might be found controlling. To be weighed against these advantages is the slight possibility that harmful defamatory silence might result from refusing to answer questions on this ground.

${ }^{52}$ It should be noted that Whittaker Chambers repeated charges made during the hearings in a radio broadcast for the purpose of giving Alger Hiss an opportunity to sue. N.Y. Times, $\S \mathbf{r}$ p. I, col. 2 (Sept. 28 , I948).

* This note deals with the 1947 and 1948 Acts. Recent legislation extending controls leaves unresolved many of the problems raised by the earlier legislation, and is discussed in an addendum, infra p. 566.

× 6I Stat. 193 (1947), 50 U.S.C.A. $\$ \S 1891-96,1898-1903$ (Supp., r947). The Act was extended for thirty-one days by Public Law 422, 8oth Cong. 2d Sess., 5० U.S.C.A. App. $\$ \S \mathrm{I} 884(\mathrm{a}), \mathrm{I} 894(\mathrm{a})$, ( $\mathrm{f}$, and subsequently amended by the Housing and Rent Act of $\mathrm{I} 948$, 62 Stat. 93 (I948), 50 U.S.C.A. $\$ 512$ (Supp., 1948). For an analysis of the entire Act see Willis, The Federal Housing and Rent Act of 1947,47 Col. L. Rev. III8 (I947). The I948 Act expired March 3I, x949. 
to preserve social stability during the postwar housing emergency while providing for a relaxation of controls in instances where rent control was no longer required. ${ }^{2}$ Section 202 (c)(I) of the original Act specifically excludes from control:

those housing accommodations, in any establishment which is commonly known as a hotel in the community in which it is located, which are occupied by persons who are provided customary hotel services; such as maid service, furnishing and laundering of linen, telephone and secretarial or desk service, use and upkeep of furniture and fixtures and bellboy service.

However, congressional failure more specifically to define the term "hotel" has raised serious doubt as to the controlled or decontrolled status of certain types of urban establishments. Urban centers are characterized by a type of multi-unit dwelling, containing separate, furnished permanent living accommodations, usually including kitchen facilities. Residents of these units receive certain special services as an element of their rental fee. Although these dwellings have become known as "apartment hotels," they differ basically from the regular hotel in that they seldom accommodate any transient guests. Whether these units are "hotels" within the Housing and Rent Act of $1947-48$ is a problem that has affected thousands of urban dwellers and is at present a source of bitter litigation.

Recently, a federal district court was squarely confronted with this issue in Adler v. Northern Hotel Company, ${ }^{3}$ a triple-damage suit brought by a group of tenants against their landlord for rental charges in excess of the maximum rent ceilings. The court stated that the essential attribute of a hotel is the presence of transient accommodations. It therefore concluded that the "Winshire Arms Apartment Hotel," a residential unit containing only permanent tenants, would not be considered a "hotel" subject to the decontrol provisions of the Housing and Rent Act, even though the required services were provided and the establishment was commonly known as an apartment hotel. 4 The court added that the unit in question must more properly be considered an apartment building in which certain special services were merely additional facilities compensated for in the monthly rental. This decision clearly contradicts the administrative interpretation of Section 202 (c)(r), issued by the Office of the Housing Expediter, which stated that "hotel" as used in the Act included all types of hotels such as

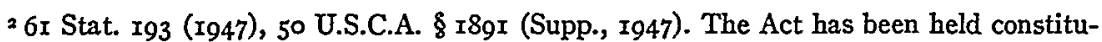
tional on the ground that the legislation was a valid exercise by Congress of its war powers, despite the cessation of hostilities, in order to cope with the housing situation created by the war. Woods v. Cloyd W. Miller Co., 333 U.S. I38 (I948).

380 F. Supp. 776 (IIl., I948). The court permitted recovery of single damages only because rent overcharges had not been made wilfully and in bad faith. See note 8 infra.

4 In Woods v. Oak Park Chateau Corp., Civil Action 48-C-I854 (D.C. Ill., I949), arising after the Adler case was decided, the court based its holding that the building was not a hotel on the absence of adequate hotel services and the fact that the building was not commonly recognized as a hotel in the community. Accord: Woods v. Lincoln Shore Apts., Civil Action 48-C-1480 (D.C. III., I949). 
transient hotels, residential hotels, apartment hotels, and family hotels. 5 Prior to this decision the practical result of the statutory language and administrative regulations had been to remove rent control protection not only from persons who reside permanently in transient hotels and semi-transient residential hotels but also from persons living in apartment hotels catering solely to permanent tenants. The removal of controls has had a marked effect on rental rates ${ }^{6}$ and has affected substantial numbers of urban dwellers who reside permanently in "apartment hotel" accommodations. "If the view in the Adler case is upheld, an

5 I3 Fed. Register 3673 (I948).

- The Housing Expediter's survey of rent increases in transient hotels in 739 major cities for the period July-December I947 estimated:
In 68 cities ( 9.2 per cent) there had been no general increases.
In 73 cities ( 0.9 per cent) the average increase ranged up to ro per cent.
In 189 cities (25.6 per cent) the average increase ranged from II to 20 per cent.
In 309 cities (4I.8 per cent) the average increase ranged from 21 to 40 per cent.
In $6 I$ cities (8.2 per cent) the average increase ranged from $4 I$ to 60 per cent.
In 39 cities (5.3 per cent) the average increase ranged from 61 to I00 per cent.

Studies by Harris, Kerr, Forster \& Co., a firm of hotel accountants, showed an increase in New York transient hotel rates of 17 per cent for the period December 1946 to December I947; studies by Horwath and Horwath, another firm of hotel accountants, showed that transient hotel rates in New York had increased 16 per cent for the same period. Hearings before a Subcommittee of the Senate Committee on Banking and Currency, Extension of Rent Controls, 8oth Cong. 2d Sess., at 885, 899 (1948); Hearings before Senate Committee on Banking and Currency, Extension of Rent Controls, 8oth Cong. 2d Sess., at 56 (I948).

The same survey by the Housing Expediter of residential hotel rentals in 730 major cities throughout the nation for the period July-December 1947 indicated:

$$
\begin{aligned}
& \text { In } 25 \text { cities ( } 34.4 \text { per cent) there had been no general increases. } \\
& \text { In } 24 \text { cities ( } 3.3 \text { per cent) the average increase ranged up to ro per cent. } \\
& \text { In } 79 \text { cities ( } 10.8 \text { per cent) the average increase ranged from II to } 20 \text { per cent. } \\
& \text { In I99 cities ( } 27.3 \text { per cent) the average increase ranged from } 21 \text { to } 40 \text { per cent. } \\
& \text { In IrI cities (I5.2 per cent) the average increase ranged from } 4 \pi \text { to } 75 \text { per cent. } \\
& \text { In } 35 \text { cities ( } 4.8 \text { per cent) the average increase ranged from } 76 \text { to } 100 \text { per cent. } \\
& \text { In } 31 \text { cities ( } 4.2 \text { per cent) the average increase ranged from ror to } 300 \text { per cent. }
\end{aligned}
$$

Hearings before Senate Committee on Banking and Currency, Extension of Rent Controls, 8 oth Cong. 2d Sess., at 56 (1948). Prof. M. Finkelstein, a member of the New York Temporary City Housing Rent Commission, testified that increases in rents for permanent hotel units in New York City ranged from 25 to 400 per cent of the former controlled rentals. Hearings before a Subcommittee of the Senate Committee on Banking and Currency, Extension of Rent Controls, 8 oth Cong. 2d Sess., at 555, 574 (I948). Mr. Alex Elson, Chairman of the Temporary Community Housing Rent Commission of Chicago, presented figures for the period from August 1947 to February 1948 , showing increases in rentals in 249 hotels in Chicago ranging from 16 to 333 per cent over former rentals. However, Mr. D. J. O'Brien testified that the American Hotel Association had conducted a survey of 348 residential hotels and that for the period July-December 1947 the average increase in rates for permanent accommodations was I8 per cent. Hearings before a Subcommittee of the Senate Committee on Banking and Currency, Extension of Rent Controls, 8oth Cong. 2d Sess., at 886 (I948). Mr. Allan George, a member of the firm of Harris, Kerr, Forster \& Co., specialists in hotel accounting, testified that increases in New York City residential hotel rates from December $x 946$ to December 1947 ranged from to to 20 per cent. Hearings before House Committee on Banking and Currency, Extension of Rent Controls, 8oth Cong. 2d Sess., at 279 (1948).

7 Because of the rental increases resulting from the Act, local city ordinances have been passed recontrolling residential and transient hotel rates as of June 30, r947: New York City Charter and Admin. Code (Supp., I948), \& U4r-6.o; Chicago Ordinance of July 2, r947 (subsequently held invalid in Ambassador East, Inc. v. Chicago, 399 Ill. 359, 77 N.E. 2d 803 [x948], on the ground that the Illinois Community Emergency Housing Rent Control law excluded all hotels from local control); Los Angeles Ordinance No. 9 r, 961 (I947); San Francisco 
incalculable number of rent increases imposed on tenants by apartment hotel landlords in the belief that their units were decontrolled will be subject to attack in triple damage suits. ${ }^{8}$ Both the litigation-breeding aspects of the I947-48 Act and the imminent prospect of new rent-control legislation make the issue one of vital currency. 9

The confusion arising from legislative failure adequately to define "hotel" has been increased by uncertainty as to the validity and effect of the administrative procedures adopted. The Housing Expediter has issued regulations which attempted to establish definitive criteria and procedures for decontrol of units "commonly known as hotels," but subsequent congressional disapproval forced recision of the regulations. The result has been needlessly to complicate the basic problem created by the indefinite statutory wording.

Hotels, like all other housing accommodations, had come within the orbit of federal price regulation under the Emergency Price Control Act in I942.0 The unusual amount of travel made necessary by the war had created great pressure on the price of hotel rooms, and controls had therefore been necessary to prevent the skyrocketing of prices. By February I947, however, the shortage of transient accommodations had abated to the point where it appeared that abandonment of price controls would not lead to extreme price increases. Consequently, OPA Rent Regulations were amended on February I5, I947, to permit individual decontrol of daily rates for transient rooms. ${ }^{\text {.x }}$ The belief that the supply of and demand for transient hotel rooms had become sufficiently normal to keep prices within reason proved sound, and average daily transient hotel rates did not increase exorbitantly after February $19477^{\text {I2 }}$

In order to effectuate an orderly decontrol process of eligible units, the Housing Expediter, pursuant to Section $204(\mathrm{~d})^{{ }^{2} 3}$ of the Housing and Rent Act, issued

Ordinance No. 4524 (Series of 1939), as amended by Ordinance No. 4539 (1947). Some of these ordinances fix rents at $I_{5}$ or 25 per cent above June 30 , 1947 levels.

${ }^{8}$ It should be noted, however, that Section 205 of the Housing and Rent Act requires the landlord to establish that he had not "wilfully" charged rents in excess of maximum rental ceilings. Insofar as landlords have relied on administrative interpretations stating that apartment hotels were decontrolled, it would seem that the courts will allow recovery of single damages only. Cf. Adler v. Northern Hotel Co., 80 F. Supp. 776 (Tll., r948).

' Section 205 establishes a one-year statute of limitations period for causes of action arising under the Act. Therefore, this problem will remain current under any new act, in the absence of special legislation.

${ }^{10}{ }_{5}^{6}$ Stat. 23 (x942), as amended, 5o U.S.C.A. App. \& gor (r942).

Ir Rent Regulations for Transient Hotels, Residential Hotels, Rooming Houses, and Motor Courts, $\$ 4(\mathrm{k})$, added by Amend. I02, I2 Fed. Register 395 (1947). While the landlord was required to file an application for decontrol, the unit was automatically decontrolled upon such filing with the OPA, subject to reinstatement if the landlord failed to submit adequate records on request or if the application contained material misrepresentation of fact.

sa See note 6 supra.

${ }_{33}$ "The Housing Expediter is authorized to issue such regulations and orders, consistent with the provisions of this title, as he may deem necessary to carry out the provisions of ... section 202(c)." 6I Stat. I93, \& 204(a) (I947), 50 U.S.C.A. § I894(d) (Supp., I947). 
Rent Regulations and interpretations designed to make more concrete the provisions of Section 202 (c)(I). The Rent Regulations originally stipulated that unless the landlord filed an application for decontrol within a certain period the accommodation would remain subject to control. ${ }^{\mathrm{x}}$ However, the congressional committees informed the Expediter that he lacked the power to make such filing a condition precedent to decontrol, and the regulation was therefore altered on August 22, I947, so that accommodations would not remain under control in case of failure to file. ${ }^{x 5}$ Administrative supervision was further attenuated by the regulations promulgated on June $3^{\circ}$, I 948 , pursuant to the Housing and Rent Act of I948. These regulations require only the filing of a "Report of Decontrol," "16 evidently solely for informational purposes, as the Expediter has recently stated "the question as to whether a particular hotel unit is decontrolled or not depends entirely upon the application of the law to the particular facts." ${ }^{17}$

Because of the early repeal of the compulsory filing provisions, many hotel landlords failed to file the requisite application and proceeded to raise rents, believing their establishments automatically decontrolled. Thus, in many instances in which the status of buildings as "hotels" was doubtful, landlords demanded and received increased rentals to which they might not have been legally entitled. Most landlords, however, voluntarily filed applications for decontrol orders. Initially such applications were processed in accordance with the section of Rent Procedural Regulation No. $\mathrm{I}^{\mathrm{I8}}$ which empowered the local Rent Director to "make such investigation of the facts, hold such conferences, and require the filing of . . . evidence." However, later administrative findings have for the most

14 Controlled Housing Rent Regulations $\S$ I(b)(7)(iii), I2 Fed. Register 4332 (I947).

${ }^{25}$ Controlled Housing Rent Regulations, Amend. 2 § 2, I2 Fed. Register 5697 (I947). Considerable controversy existed as to whether decontrol of hotels was self-effectuating. In Woods v. Benson Hotel Corp., 75 F. Supp. 743 (Minn., I948), aff'd on other grounds 168 F. 2d 694 (C.C.A. 8th, I948), the court upheld the validity of requiring applications for decontrol, stating that Section 202 (d) "authorize[d] the Expediter, if he deems it advisable, (as he has), to require an orderly process of decontrol; that is, those who believe themselves within the exception of section 202(c) can be required to file application with the Expediter, who must approve them before decontrol is effectuated. ... Such a requirement by the Expediter does not seem onerous, objectionable or a transgression of his statutory authority. The only alternative would be to leave each person, if he believed himself to be decontrolled, to act at his peril. There would be no administrative procedure to which he could have recourse to determine his rights. Such a policy would be chaotic. ..." However, in subsequent hearings before the House Committee on Banking and Currency, Chairman Wolcott stated, "[I]t was very clearly brought out that he [the Housing Expediter] could not write the law into his regulations by stating that the property was not decontrolled unless an application for decontrol was filed. ..." Hearings before House Committee on Banking and Currency, Extension of Rent Controls, 8oth Cong. 2d Sess., at 204 (r948); see Woods v. Boss Hotels Co., No. 304, Civil Cases (D.C. Towa, 1947).

${ }^{16}$ Controlled Housing Rent Regulation, I3 Fed. Register 3630 (I948).

x7 Questions and Answers on Types of Accommodations Decontrolled under the Housing

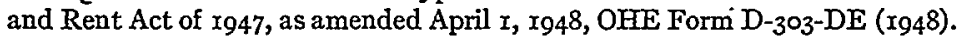

${ }^{18}$ Rent Procedural Reg. No. $x, \S 840.18$, x2 Fed. Register 5916 (I947). 
part been based solely on the ex parte statements in the landlord's application. ${ }^{19}$ Landlords who received such orders believed their units decontrolled as a matter of law and proceeded to raise rents. Tenants, confronted by such orders, also believed that they were determinative of the status of the building and acquiesced in the rent increases. However, nowhere in the Act or the regulations is any provision made for an absolute order of decontrol, and therefore administrative decontrol orders have not been considered binding determinations and have been reviewed in connection with suits for damages under the Act. ${ }^{20}$ It should be noted that the Act affords landlords and tenants no express right of direct judicial review of the Expediter's orders. ${ }^{22}$ The issue of the finality of decontrol orders can be raised by tenants only in suits for rent overcharges, since such suits are the sole right of action expressly granted tenants by the Act.

In addition to issuing regulations in the area of administrative procedure, the Housing Expediter also attempted to solve the basic problem under the Actthe definition of "hotel." The initial Rent Regulations provided that "if $75 \%$ or more of the units in the establishment are self-contained dwelling units ... or were rented on other than a daily term of occupancy on June 30, I947," the establishment was not to be considered a hotel.2 This qualification was deleted on August 8, $1947,{ }^{23}$ after the congressional committees informed the Housing Expediter that the limiting provision was inconsistent with congressional intent. ${ }^{24}$ In a later attempt to establish a clear-cut standard for decontrol, the Housing Expediter issued a regulation which substituted the word "including"

19 Decreased personnel and lack of funds have necessitated the abandonment of investigations into the properties involved. There is no method presently available to check on the validity of the information submitted. As a result the Chicago Area Rent Director now extends only an advisory opinion as to whether the unit has been decontrolled.

20 Administrative action of the Housing Expediter in regard to application for decontrol did not preclude judicial determination of whether the premises were or were not within the hotel exception of Section $2 \mathrm{O}_{2}$ (c), in connection with a suit for treble damages under the Housing and Rent Act of I947. Adler v. Northern Hotel, 80 F. Supp. 776 (IIl., I948); Woods v. Boss Hotels Co., No. 304, Civil Cases (D.C. Iowa, I947); Stanley v. Richman, No. 553 (Super. Ct., Los Angeles, Calif., 1947) opinion reprinted in Los Angeles Daily Journal (Nov. 26, I947). Contra: Morris v. Ray, Civil Action 9652 (D.C. Ill., 1948).

2t Koster v. Turchi, 79 F. Supp. 268 (Pa., r948). Section 2(a) of the Federal Administrative Procedure Act, 5 U.S.C.A. \& I00r(a) (1947), has been re-amended, 50 U.S.C.A. App. \& r9o (I947), so as to exclude from its operation the functions conferred by the Housing and Rent Act of 1947 . There is no provision for the granting of any injunctive relief upon the application of a tenant or a landlord. Fox v. 34 Hillside Realty Corp., 79 F. Supp. 832 (N.Y., I948); Spieler v. Haas, 79 F. Supp. 835 (N.Y., I948); Iuftman v. Ross, 75 F. Supp. 627 (N.Y., I948); Poirier v. Desillier, 75 F. Supp. 402 (Mass., I947).

z Controlled Housing Rent Regulations \& x, x2 Fed. Register 433 I (1947).

23 Controlled Housing Rent Regulation, Amend. I, § I, I2 Fed. Register 5454 (I947).

24 Hearings before House Committee on Banking and Currency, Extension of Rent Controls, 8oth Cong. 2d Sess., at 205 (1948); Hearings before a Subcommittee of the Senate Committee on Banking and Currency, Extension of Rent Controls, 8oth Cong. 2d Sess., at 324 (I948). In Creedon v. Vanier (D.C. Texas, I947), an unreported opinion, the court held the 75 per cent proviso to be "outside of the Act and not justified by the Act" 
for the legislative phrase "such as" in defining the requirement of "customary hotel services" under the Act.25 The effect of this regulation was to require that all services specified in the law must have been present as of June 30 , I947, before housing accommodations could be decontrolled. As a result, application of the Act was primarily limited to transient and semi-transient accommodations, since only such units commonly provide all the specified services. The Expediter also construed the phrase "provided customary services" to mean that customary hotel services must have been received by tenants ${ }^{26}$ and not merely made available to them. This too was a limiting provision, since units otherwise eligible for decontrol would remain subject to regulation if the tenant supplied his own furniture, linens, maid service, etc. These administrative interpretations were challenged in Woods v. Benson Hotel Corporation, ${ }^{27}$ but the court held that insertion of the word "including" into the regulation was a valid exercise of the regulatory power of the Expediter. The Court also held "that the services which are provided must actually be received by the tenants." However, in hearings on the Housing and Rent Act of $x 948^{28}$ the congressional committees declared that this interpretation by the Expediter was also expressly contrary to the intent of Congress $^{29}$ and that not all of the services mentioned need be provided, as long as those provided met the standard of customary hotel services in the community. Furthermore, it is only necessary that these services be made available to, and not received by, tenants. The Housing Expediter has amended his regulations accordingly. ${ }^{30}$

The abrogation of administrative "tests" plus the ambiguity inherent in the statutory usage of "hotel" has compelled the courts to undertake the problem of determining the proper meaning of the term. In the few decisions interpreting Section $202(c)(I)$ prior to Adler v. Northern Hotel Company, the courts have emphasized certain criteria in giving content to the phrase "commonly known as a hotel in the community." The mere presence of the word "hotel" in the name of the establishment is clearly not determinative of the nature of the building. ${ }^{3 x}$

${ }_{25}$ Controlled Housing Rent Regulation, I2 Fed. Register 5457 (I947).

${ }_{26}$ Housing and Rent Memorandum No. 2 (Sept., 1947).

${ }^{27} 75$ F. Supp. 743 (Minn., I948), aff'd on other grounds I68 F. 2d 694 (C.C.A. 8th, I948). The court interpreted the phrase "such as" to mean not only the five services enumerated in the Act, but also to include any other services which were customary in the community.

${ }^{28} 62$ Stat. 93 (I948), 50 U.S.C.A. $\$ 5$ I2 (Supp., I948). No change was made in Section $202(c)(x)$.

${ }^{29}$ H. Rep. I6II, 8oth Cong. 2 d Sess., at 9 (I948); S. Rep. 896, 8oth Cong. 2 d Sess., at 8 (I948).

${ }^{30}$ Controlled Housing Rent Regulations $\S$ I(b)(2)(i), I3 Fed. Register 3629 (I948). But at least three basic services must be provided: furniture and fixtures, maid service, and furnishing and laundering of linen. I3 Fed. Register 433 (I948).

${ }^{3 x}$ Adler v. Northern Hotel Co., 80 F. Supp. 776 (Ill., r948); Woods v. Drolson Co., 75 F. Supp. 758 (Minn., r948); Stanley v. Richman, No. 553 (Super. Ct., Los Angeles, Cal., 1947), opinion reprinted in Los Angeles Daily Journal (Nov. 26, r947); cf. Wiatt Operating Co. v. Goldfogle, I2I N.Y. Misc. 34I, 20I N.Y. Supp. 262 (I923); Roberts v. Case Hotel Co., 106 N.Y. Misc. 481 , I75 N.Y. Supp. I237(I9I9). 
In Woods v. Drolson Company ${ }^{32}$ the court held that, although state and local hotel licenses had been obtained and a sign saying "Vine Hall Hotel" hung out in front, a building which contained furnished kitchenette apartments, did not have transient guests, and had laundry facilities and mailboxes of an ordinary apartment house, was not a hotel subject to decontrol. In Woods v. Boss Hotels Company ${ }^{33}$ the absence of transient guests was considered one of the significant factors in deciding that the building in question was not a hotel, even though it was licensed as the "Commonwealth Apartment Hotel" under an Iowa statute and was listed as an apartment hotel in the telephone book and national and state hotel directories. In Stanley v. Richman ${ }^{34}$ the court held that an "apartment hotel" containing furnished kitchenette apartments and inhabited solely by permanent tenants was merely an apartment house and therefore not decontrolled, although maid service, linens, and the use and upkeep of furniture and fixtures were provided. In Woods v. Western Holding Corporation, ${ }^{35}$ a building which provided transient accommodations was held to be a hotel under the Act, the court relying most heavily on the provisions for limited maid service, bellboy service, desk service, and the use and upkeep of furniture and fixtures and the building's classification as a hotel under a state licensing statute. It appears from these decisions that one of the most important elements in determining whether an establishment could be "commonly known as a hotel" was the presence or absence of transient facilities, thus foreshadowing the decision in the Adler case.

In the hearings, committee reports, and congressional debates, repeated

3275 F. Supp. 758 (Minn., I948). This was a suit brought by the Housing Expediter to enjoin defendants from charging over-ceiling rents and to compel refunds to tenants of any over-ceiling rents already collected. The court also took into consideration the following facts: The building lacked telephone service, desk service, and bellboy service, although providing other limited hotel services. It was not advertised as a hotel or listed in the telephone directory as a hotel. The entrance to the building was locked at night, tenants having their own keys.

${ }_{33}$ No. 304 , Civil Cases (D.C. Iowa, I947). This also was a suit brought by the Housing Expediter to compel refunds. The unit in question was a six-story building located in a residential district, containing IIo separate accommodations, almost entirely tenanted by permanent residents. The building possessed a lobby, a public dining room, public parlors, and complete desk service with two clerks on duty during the day. Some of the units were unfurnished and maid service and linens were available at extra cost. Six units were leased on a weekly basis and 104 on a monthly basis.

34 No. 533 (Super. Ct., Los Angeles, Cal., 1947), opinion reprinted in Los Angeles Daily Journal (Nov. 26, 1947).

${ }^{35} 77$ F. Supp. 90 (I948), aff'd I 7 U.S.L. Week 246r (C.A. 8th, I949). In sustaining the trial court's findings of fact, the court used some broad language in regard to the decontrol status of all hotels. However, the building in question was a semi-transient residential unit, and therefore this decision may be limited in its application to units of this type. In addition, the court was only passing on the trial court's findings of fact; in regard to whether the unit was commonly known as a hotel in the community the court stated: "This was a question of fact for the determination of the trial court. . . . We do not think the evidence on this question was of such character as to compel the findings made by the trial court but the question before us is not whether the findings are such as this court might have made on the same evidence but whether it can be said that these findings are clearly erroneous." 
statements were made that Congress intended to decontrol all "hotels." But emphasis was placed throughout on the transient character of the accommodations to be decontrolled; $;^{6}$ the application of this section to units containing only permanent residents was not envisaged. 37 It has been contended that congressional refusal in I948 to pass legislation recontrolling permanent living quarters in hotels ${ }^{38}$ meant that Congress had originally intended to decontrol all "hotel" units and was unwilling to alter that original intention. It is questionable, however, whether this argument is valid in its application to units containing only permanent tenants. Senator Baldwin, one of the draftsmen of recontrol legislation, has implied that such units were not decontrolled by the original Housing and Rent Act, ${ }^{39}$ thus limiting the application of his bill to permanent accommodations in transient and semi-transient hotels.

${ }^{36}$ Sen. Cain, 94 Cong. Rec. 1458 , I594 (r948): "The thought of the provision as a whole is to exclude from control hotels serving transient guests. Under the language of the bill, many hotels used for residential purposes are kept under federal control." Rep. Wolcott, 94 Cong. Rec. 2963 ( $x 948$ ): "We decontrolled transient rooms and we decontrolled finally those rooms in hotels occupied by these so-called permanent guests where they were receiving hotel services ... for the reason that the increase in the cost of these services justified it. . . We took into consideration an amendment which had been offered to the bill in the Senate [which expressly provided for decontrol of transient apartments, residential and family hotels] which we were not in agreement with, because it broadened the issue and we could not broaden it to the point where it would have nullified our intent and would decontrol, perhaps, a great many accommodations which we did not intend to decontrol in this field. The [present] language ... seemed to be the most desirable compromise between the extremes of no control at all and some control over these properties"; Rep. Monroney, Hearings before House Committee on Banking and Currency, Extension of Rent Controls, 8oth Cong. 2d Sess., at 215 (r948): "The transient character was pretty strongly in the minds of this committee, as being one of the major tests on that housing which we were seeking to decontrol. . . . Mr. Vanderslice [the witness] has so often repeated that the intent of Congress was to decontrol completely the residential hotels that I would like to call to the attention of the committee the statement of the committee in the report, in which it is pretty clearly pointed out, I think, that the exemptions . . . took into consideration the transient character of the places. It says: [readingl 'In the case of hotel, tourist home and motor court housing accommodations catering principally to transients, whose costs of operation consist in substantial measure of personal services which have increased considerably.' And then on page I4: 'The second category consists of hotel accommodations occupied by persons who are provided customary hotel services, motor courts, and tourist homes serving transient guests exclusively. So ... the committee twice has written in the report to the effect that we were attempting to decontrol transient accommodations."

${ }^{37} 93$ Cong. Rec. 6055 (

"Mr. CoNNAILY:... As I understand, if it were a residential hotel, it would not be subject to control. What is a residential hotel?

[Interruption...]

"MR. TAXIOR: A residential hotel is a hotel with a certain percentage of permanent guests ... a certain percentage of the rooms or accommodations is rented on a permanent basis.

[Interruption...]

"MR. FULBRIGHT: Yes; this question involves a determination of the definition. A similar question is involved in determining what is a residential hotel. A certain percentage of the accommodations must be rented on a permanent basis.

"MR. Connally: Suppose all the rooms were rented on a permanent basis?

"MR. FULBRIGHT: Then I think it would become an apartment house [and therefore not subject to decontrol]."

${ }^{38}$ S. 2015, 8oth Cong. 2 d Sess. (1948).

39 Senator Baldwin, in discussing his proposed bill before the senate committee, emphasized the element of transiency as being a necessary requisite under the original Act when he 
Congress undoubtedly intended to remove controls from permanent residents of transient and semi-transient residential hotels ${ }^{40}$ because of increased costs, ${ }^{4 \mathrm{~T}}$ decreased hotel occupancy, ${ }^{42}$ and because the "great bulk" of the units decontrolled were luxury accommodations. It was also stressed that not more than Ioo,000 such units in the country would be affected by the decontrol provision. .3 However, it is doubtful whether these reasons are applicable to the decontrol of self-contained living accommodations in units catering predominantly to permanent tenants. From an analysis of percentage of occupancy ${ }^{44}$ and number of

stated: "[W] here you have a small hotel that is essentially a residential hotel it is always possible for them, by the subterfuge of taking in a few transients, to remove the thing entirely from all rent control." Hearings before a Subcommittee of the Senate Committee on Banking and Currency, Extension of Rent Controls, 8oth Cong. 2d Sess., at 2 II (I948).

${ }^{40} \mathrm{H}$. Rep. r6rr, 8oth Cong. 2d Sess., at 9 (I948); S. Rep. 896, 8oth Cong. 2d Sess., at 8 (r948); H. Rep. 3I7, 8oth Cong. xst Sess., at I7 (I947); Rep. Wolcott, 94 Cong. Rec. 2963 (I948); Hearings before House Committee on Banking and Currency, Extension of Rent Controls, 8oth Cong. 2d Sess., at 203, 216 (I948).

${ }^{41}$ H. Rep. 317,80 th Cong. Ist Sess. (r947); H. Rep. I560,80th Cong. 2d Sess. (r948); 94 Cong. Rec. 2963 (r948); Hearing before House Committee on Banking and Currency, Extension of Rent Controls, 8oth Cong. 2d Sess., at 203 (1949). Representatives of hotel groups testified that 60 per cent of the total operating costs of hotels are incurred for services rendered directly or indirectly to guests and that it was mainly the cost of providing such services that had increased the operational costs. Labor costs represented $5 \circ$ per cent of the over-all service cost figure, and, according to figures of the United States Bureau of Labor Statistics, average hourly wage rates in hotels in 1947 had increased 96 per cent since r939. The commodity price index, reflecting costs of materials and supplies used by hotels advanced 79 per cent from r940 to December 1946. Hearings before House Committee on Banking and Currency, Housing and Rent Control, 8oth Cong. xst Sess., at 267 (I947); Hearings before a Subcommittee of the Senate Committee on Banking and Currency, Extension of Rent Controls, 8oth Cong. 2d Sess., at 889 (1948). Mr. J. E. Frawley, Chairman of the Board of the American Hotel Association, testified that concurrent with cost increases, transient hotel earnings had declined since 1944. Hearings before Senate Committee on Banking and Currency, Rent Controls, 8oth Cong. Ist Sess., at 270 (I947); see also testimony of Mr. G. J. Sherrard of the American Hotel Association, Hearings before House Committee on Banking and Currency, Extension of Rent Controls, 8oth Cong. 2d Sess., at 274 (I948). Although there is a great disparity between increases in costs incurred by units accommodating transient guests and units accommodating permanent tenants, it is difficult to determine from an analysis of cost increases alone whether Congress intended to restrict decontrol to transient units only.

${ }^{42}$ Sen. Buck, 93 Cong. Rec. 6042 (x947); Hearings before House Committee on Banking and Currency, Housing and Rent Control, 8oth Cong. Ist Sess., at 276 (I947); Hearings before House Committee on Banking and Currency, Extension of Rent Controls, 8oth Cong. 2d Sess., at 280 ( 1948$)$.

${ }^{43}$ Sen. Buck, 93 Cong. Rec. 6042 (I947); Hearings before Senate Committee on Banking and Currency, Rent Control, 8oth Cong. Ist Sess., at 387 (1947); Hearings before House Committee on Banking and Currency, Housing and Rent Control, 8oth Cong. Ist Sess., at 267 (1947); Hearings before a Subcommittee of the Senate Committee on Banking and Currency, Extension of Rent Controls, 8oth Cong. 2d Sess., at 888, 9r9 (1948).

${ }_{44}$ While there was a definite trend toward lowered occupancy in transient hotels, the percentage of occupancy in residential and apartment hotels has increased. Thirty-two New York hotels had an average occupancy of 79 per cent of capacity in December 1947 against 86 per cent in December 1946. Hearings before House Committee on Banking and Currency, Extension of Rent Controls, 8oth Cong. 2d Sess., at 280 (I948). In Detroit, average occupancy was 86 per cent of capacity during r947, as against 97 per cent during the war period. Hearings before House Committee on Banking and Currency, Housing and Rent Control, 8oth Cong. 
units affected, 45 it would seem that the legislature was considering only transient and semi-transient hotels when it ordered decontrol, and not "hotels" catering solely to permanent tenants, even though such units received customary hotel services. Such units are more like apartment buildings, certain special services being reflected in the rent paid. $4^{6}$

Even if legislative history is not considered conclusive in establishing congressional intent, definitions of "hotel" established by common usage, employment in other statutes, and analogous judicial decisions also indicate that the primary requisite of a hotel is accommodation for transients. Exclusively permanent residential units would be incompatible with such a requirement. In the absence of concise statutory language clearly establishing a different meaning, ${ }^{47} \mathrm{Con}-$ gress must be presumed to have used the word "hotel" in its commonly recognized connotation..$^{8} \mathrm{~A}$ "hotel" is legally equivalent to the old "inn," which was commonly defined as a place where all transient persons who arrived would be received and entertained as guests for compensation. ${ }^{49}$ This legal meaning corresponds to the commonly accepted definition as "a place providing lodging and usually meals for the public, especially for transients." 50 State legislation employing the word "hotel" reflects a general understanding that the term excludes buildings occupied entirely or primarily by permanent tenants. ${ }^{5 x}$ Analogous judi-

Ist Sess., at 276 (I947). Occupancy in Chicago residential and apartment hotels, however, was 93.2 per cent of capacity during the war period and 98 per cent in 1947. Hearings before Senate Committee on Banking and Currency, Extension of Rent Controls, 8oth Cong. 2d Sess., at 3 I9 (I948).

${ }_{45}$ Congress apparently failed to realize the great number of residential units that would be affected by. the decontrol provision. During debate on this section, continued emphasis was placed on the insignificant number of units that would be decontrolled; see note 43 supra. Yet in Chicago alone there are 100,000 units housing over 200,000 tenants affected by the decontrol provision. Hearings before a Subcommittee of the Senate Committee on Banking and Currency, Extension of Rent Controls, 8oth Cong. 2d Sess., at 20r (I948). In New York there are over $x_{03}, 000$ such units affecting over 200,000 tenants. Hearings before a Subcommittee of the Senate Committee on Banking and Currency, Extension of Rent Controls, 8oth Cong. 2d Sess., at 583 (1948).

${ }^{4}$ Note 3 supra.

${ }^{47}$ Cooper v. Schirmeister, 176 N.Y. Misc. 474, 26 N.Y.S. $2 d 668$ (I94I).

${ }_{48}^{8}$ Fieldcrest Dairies v. City of Chicago, I22 F, 2 I I32 (C.C.A. 7 th, I94I), rev'd on other grounds 316 U.S. I68; Luken Steel Co. v. Perkins, I07 F. 2d 627 (App. D.C., I939).

${ }^{49}$ Wiatt Construction Co. v. Chase, I97 App. Div. 327, I88 N.Y. Supp. 589 (I92I), aff'd in 233 N.Y. 633 , I35 N.E. 948 (I922); Fay v. Pacific Improvement Co., 93 Cal. 253, 26 Pac. rog9 (I89r). The furnishing of meals by the person conducting the place is no longer regarded as an essential characteristic of a hotel or inn. Metzler v. Terminal Hotel Co., I35 Mo. App. 4Io, II5 S.W. 1037 (Ig08); Johnson v. Chadbourne Finance Co., 89 Minn. 3 Io, 99 N.W. 874 (Ig03).

$5^{\circ}$ Webster's New International Dictionary (2d ed., r947).

5x D.C. Code (I940) $\$ 5-3 \times 2$ defines a hotel as a building in which meals are served and rooms are provided for the accommodation of ro or more transients; Idaho Code Ann. (Supp. x932) $\$ 38-x 30 x$ defines a hotel as a building where sleeping accommodations are furnished for hire to transient guests, whether with or without meals; Wash. Rev. Stat. Ann. (Remington, 
cial decisions determining the status of "apartment hotels," or of similar types of residences which cater to permanent tenants but which offer services akin to those offered by a hotel, have held that such units are not "hotels." these decisions have considered the applicability of a specific statute to the unit in question, ${ }^{53}$ and the existence of transient accommodations was considered one of the most important attributes of a "hotel."

While the arguments outlined cannot be said conclusively to support the proposition that apartment hotels containing only permanent residents were not decontrolled by the Housing and Rent Act, neither can it be definitely stated that every type of hotel was decontrolled by the Act. More important than either conclusion, however, is the undeniable fact that endless confusion and uncertainty have arisen because of the ambiguous statutory language. This result has caused serious hardship not only to tenants who have been subjected to unwarranted rent increases but also to landlords who are now confronted with the prospect of triple damage suits. ${ }^{54}$ Proposed legislation now pending

1932) $\$ 6860$ defines a hotel in the usual manner but requires a minimum of 15 rooms; Minn. Stat. (Mason, 1945) § I57.01: not a hotel if rental for periods of more than a week. Several states use the word "hotel" in their statutes without definition, but the use of the term clearly refers to transient accommodations: Pa. Stat. Ann. (Purdon, 1930) tit. 37, \&6r, Colo. Stat. Ann. (Michie, I935) c. 8I, \$§ I, 3, 5; Mass. Ann. Laws (r942) c. I40. The New York Multiple Dwelling Law provides regulations for all multiple dwellings, dividing such dwellings into two classes. Section 8 defines a "Class A" building as "a multiple dwelling which is occupied as a rule for permanent residence purposes. This class shall include . . . apartment houses, apartment hotels... kitchenette apartments, and all other multiple dwellings except Class B multiple dwellings." Section 9 defines a "Class B" multiple dwelling as a "multiple dwelling which is occupied as a rule transiently ... this class shall include hotels...." Section I2 defines a "hotel" as an inn having 30 or more sleeping rooms. N.Y. Ann. Law (McKinney, r929) c. $7 x_{3}, \S \S 8,9$, I2. The following state statutes follow New York's statute, placing apartment hotels in "Class A" while placing hotels in "Class B": Iowa Code (r946) c. 4I3; Mich. Stat. Ann. (Henderson, 1936) $\$ 5.2772$; Neb. Rev. Stat. (I943) §\& 4I-Ior, 4I-Io3. Illinois Innkeeper statutes seem to contain two separate definitions of "hotel." Hotel is defined as any building where lodging, food, apartments, suites or other accommodations are offered to guests, whether transient, permanent, or residential, which contain 25 or more rooms. Ill. Rev. Stat. (I947) c. 7I, $\&_{4}$ (c), under the Act headed "Protection of Innkeepers." Under an act headed "Safety Appliances," a hotel is defined as any building containing ten or more rooms which is held out to the public as a hotel ... when sleeping accommodations are furnished for hire to transient guests, whether with or without meals. Ill. Rev. Stat. (r947) c. 7I, §5. The same definition is contained in Ill. Rev. Stat. (I947) C. 7I, § I4, under an act entitled "Sanitary Equipment."

sz Roberts v. Case Hotel Co., Io6 N.Y. Misc. 48r, 175 N.Y. Supp. I23 (Igrg); Wiatt Operating Co. v. Goldfogle, I2I N.Y. Misc. 34I, 20 I N.Y. Supp. 262 (1923); cf. Wiatt Construction Co. v. Chase, 197 App. Div. 327, I88 N.Y. Supp. 589 (1921), aff'd 233 N.Y. 633, I35 N.E. 948 (I922); State v. Bowman, 202 Minn. 44, 279 N.W. 214 (I938); see Williams v. Lauderdale, I9I S.W. 2d 455 (Ark., 1945).

33 See rg A.L.R. 529 (1922); 53 A.L.R. 988 (1928).

54 Since most landlords have relied on administrative interpretations and rulings in raising rents, forthcoming legislation might specifically exempt landlords from damage suits, on the same theory contained in the Fair Labor Standards Act, 6r Stat. 88 (1947), 29 U.S.C.A. $\S 25^{8}$ (I947) (reliance in good faith on previous administrative rulings, regulations, interpretations, etc., constitutes a bar to any cause of action accruing prior to the enactment of the 
before Congress must avoid the ambiguity of the present Act by recognizing the decontrol distinction between transient and semi-transient hotels and accommodations mislabeled "apartment hotels." 55

[After this note had gone to press, Congress passed the Housing and Rent

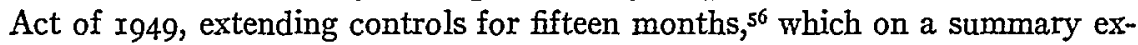
amination seems to preserve many of the complexities and ambiguities inherent in the previous Acts. The I949 Act specifically recognizes the decontrol distinction between units containing permanent and transient residents, but the application of the provision has been limited to cities containing $2,500,000$ or more residents. ${ }^{57}$ This would seem to leave still unsettled the status of units containing predominantly permanent tenants in communities having fewer inhabitants..$^{58}$ For those hotels now clearly subject to rent controls "the maximum rent shall be the rent in effect for such accommodations on March I, 1949." ${ }^{29}$ Therefore, despite the reimposition of controls, the effect of this provision is to validate the numerous rent increases received by tenants since the formulation of the original Act.

The effect of the I949 Act on present litigation is not entirely clear. Section

amendment to the Act). However, since instances of irrevocable damage are not as probable in the hotel situation as in the portal-to-portal cases, Section 205 of the present Act, which limits tenants' recovery to single damages in the absence of wilful overcharges, probably should be retained but modified to bar recovery by tenants where restitution of rent overcharges would cause hardship on landlords.

55 For specific formulas for suggested legislation, see statement of Mr. Alex Elson, chairman of the Chicago Temporary Community Housing Rent Commission before a Subcommittee of the Senate Committee on Banking and Currency, Extension of Rent Controls, 8oth Cong. 2d Sess., at ro55 (I948).

${ }^{6}$ H.R. I73I, 8rst Cong. Ist Sess. (Pub. L. No. 3I, March 30, I949).

$57 \S 202$ (c)(I)(B) exempts from control "those housing accommodations in hotels in cities of $2,500,000$ population or more ... (i) which are located in hotels in which 75 per centum or more of the occupied housing accommodations on March I, I949, were used for transient occupancy, or (ii) which are not located in hotels described in (i) but which on March $x$, I949 were used for transient occupancy [rented on a daily basis to a tenant who had not on March $r$, 1949, continuously resided in the hotel for ninety days or more]." In effect this provision limits recontrol of permanent accommodations in residential and apartment hotels to Chicago, since New York City has established local regulations.

${ }^{5}{ }^{8} \S 202(\mathrm{C})(\mathrm{I})(\mathrm{A})$ does not make any distinction based on transient or permanent occupancy, but retains the definition contained in the I947 Act, excluding from control " $t$ those housing accommodations in any establishment which is located in a city of less than 2,500,000 population ... and which is commonly known as a hotel in the community in which it is located, which are occupied by persons who are provided customary hotel services such as maid service, furnishing and laundering of linen, telephone and secretarial or desk service, use and upkeep of furniture and fixtures, and bellboy service."

$59 \S 204(\mathrm{~h})$. But this provision may not be controlling where litigation was in progress as of March I, I949 to determine whether the unit involved was or was not a "hotel." If such determination results in a finding that the unit was not a hotel within the definition contained in the I947-48 Acts, the unit would not have been properly subject to decontrol under those Acts, and presumably, the applicable rent in effect on March $x$, 1949 would be the rent paid as of June 30, I947. 
$206(d)^{60}$ provides that reliance in good faith on the Act or regulations thereunder shall constitute a bar to damage actions. Although such a provision has been suggested, ${ }^{6}$ the ambiguous wording of the section makes it doubtful whether the provision was intended to have a retroactive effect.]

60 "No person shall be liable for damages or penalties ... on any grounds for or in respect of anything done or omitted to be done in good faith pursuant to any provision of this Act or any regulation, order, or requirement thereunder notwithstanding that subsequently such provision, regulation, order, or requirement may be modified, rescinded, or determined to be invalid."

6ะ Note 54 supra. 